Studia z Dziejów Średniowiecza nr 21, 2017

\author{
Mateusz Szuba \\ (Gdańsk)
}

\title{
Data narodzin i pozycja późniejszego księcia gdańskiego Warcisława II do 1266 roku $^{1}$
}

Key words: medieval, East Pomerania, Sobiesław dynasty, genealogy, politics, feudal divisions

Postać Warcisława II, księcia gdańskiego z dynastii Sobiesławiców, jak dotąd doczekała się jedynie nielicznych biogramów i przyczynków genealogicznych ${ }^{2}$. Badacze zajmowali się jego osobą głównie w aspekcie krótkiego (1266-1269/70) panowania oraz stosunków z ojcem Świętopełkiem i bratem Mściwojem II, w tym drugim wypadku zwłaszcza wojna domową z lat $1269-1271^{3}$. Taki stan rzeczy wynika zarówno ze znaczenia powyższych wydarzeń, jak i stosunkowo małej liczby informacji źródłowych dotyczących Warcisława II. Niniejszy artykuł będzie więc stanowić próbę naświetlenia losów tego księcia przed objęciem rządów, konkretnie - wyznaczenia choćby przybliżonej daty jego narodzin oraz określenia pozycji, jaką zajmował w państwie i dynastii Sobiesławiców za życia swego ojca i jakim ulegała ona zmianom.

1 Niniejszy artykuł stanowi poprawioną i zmienioną wersję fragmentów dwóch rozdziałów pracy magisterskiej Warcisław II, ksiaże gdański (1233/38-9 V 1271), Gdańsk 2016, przygotowanej pod kierunkiem prof. dr. hab. Błażeja Śliwińskiego.

2 E. Bahr, Genealogie der pommerellischen Herzöge, ZWG 1939, H. 75, s. 48-50; idem, Wartislaw II, Herzog in Pommerellen [w:] Altpreussiche Biographie, Bd. 2, hg. v. Ch. Krollman, Magdeburg/Lahn 1961, s. 776; B. Śliwiński, Poczet ksiażat gdańskich. Dynastia Sobiestawiców w XII-XIII wieku, Gdańsk 1997, s. 53-55; idem, Warcisław II [w:] Encyklopedia Gdańska, Gdańsk 2012, s. 1079; E. Rymar, Rodowód ksiażąt pomorskich, wyd. 2, Szczecin 2005, s. 274-275 (tu obszerniejsza literatura dotycząca genealogii Warcisława II).

3 Ostatnio kwestie te szczegółowo omówili: B. Śliwiński, Mściwoj II (1224-1294). Ksiażę wschodniopomorski (gdański), Warszawa 2016 (tu starsza literatura) oraz w formie popularnonaukowej M. Smoliński, Świętopetk gdański, Poznań 2016. 


\section{I}

Źródła nie dostarczaja bezpośredniej informacji na temat daty narodzin Warcisława II, w wyniku czego sięgano do wzmianek pośrednich. Ludwig Quandt wskazał na dokument Świętopełka z data 1205 r., gdzie Mściwoj II został nazwany „,pierworodnym”, co uznał za świadectwo posiadania już wtedy przez księcia gdańskiego większej liczby synów, w tym Warcisława II. Do jego narodzin doszłoby więc jeszcze przed 1235 r., kiedy zdaniem badacza faktycznie wystawiono powyższy dyplom ${ }^{4}$. Stanisław Kujot i Ernst Bahr z kolei swoje wnioski oparli na dacie pojawienia się Warcisława II w źródłach, co miało miejsce w przywileju Świętopełka z 2 grudnia 1248 r. ${ }^{5}$ Przyjęli oni, że Warcisław II musiał mieć wtedy przynajmniej dwanaście lat, gdyż taki wiek uprawniał do wykonywania czynności prawnych. Urodziłby się tym samym najpóźniej w 1236 r., przy tym S. Kujot uznawał, iż Warcisława II nie było jeszcze na świecie w 1231 r., kiedy to w bulli papieża Grzegorza VII wymieniono tylko Świętopełka i Mściwoja II. Jednak E. Bahr dopuszczał taką możliwość, tłumacząc brak informacji o Warcisławie II jego zbyt młodym jego wiekiem, uniemożliwiającym udział w działaniach w Prusach, których dotyczył dokument ${ }^{6}$.

Szersze wnioski na omawiany temat przedstawił Edward Rymar. Uznał on Warcisława II za syna nie Eufrozyny - pierwszej żony Świętopełka, jak wcześniej twierdzono, lecz drugiej żony księcia, Ermengardy, po której miał odziedziczyć prawa do ziemi sławieńskiej. Świadczyłaby o tym przynależność tej ziemi do dzielnicy Warcisława II po objęciu przez niego samodzielnych rządów, a którą to przynależność książę podkreślał nawet po jej utracie w $1266 \mathrm{r}$. W charakterze dziedzica tego obszaru występowałby także już w młodości, udzielając zgody ojcu na kolejne czynione tutaj nadania dla klasztoru w Darguniu - najpierw w 1248 r., choć nie osiagnałby jeszcze wieku sprawnego, a następnie wspólnie z matka, 5 kwietnia 1252 r. Uzyskanie przez Warcisława II wieku pełnoletniego, czyli 20 lat, potwierdzałoby zaś pojawienie się go dopiero w dokumentach z 1257 i 1259 r. Dokumenty te odnosiły się przy tym nie

4 P 13; L. Quandt, Ostpommern, seine Fürsten, fürstlichen Landestheilungen und Districte, BS AF, Jr. XVI, 1856, H. 1, s. 101-103.

$5 \mathrm{P} 112$.

6 P 44; S. Kujot, Dzieje Prus Królewskich. Część I: Do roku 1309, RTNT, R. 20-25, 1913-1918, s. 398, 859, 866; E. Bahr, Genealogie..., s. 28, 48-49. 
do ziemi sławieńskiej, ale do pozostałych terenów państwa Sobiesławiców ${ }^{7}$. Do małżeństwa Świętopełka z Ermengardą i narodzin Warcisława II doszłoby około 1236 r., a więc w okresie opanowania ziemi sławieńskiej przez księcia gdańskiego ${ }^{8}$. Wnioski E. Rymara zaaprobowali późniejsi historycy. Również zdaniem Błażeja Śliwińskiego Warcisław II w 1248 r. nie był jeszcze pełnoletni. O jego narodzinach nie może bowiem świadczyć bulla z $1231 \mathrm{r}$. wymieniająca jedynie Świętopełka i Mściwoja ${ }^{9}$. Obecność młodszego z książąt przy nadaniach dla cystersów darguńskich wynikałaby natomiast z ich podniosłości i rodowego charakteru ${ }^{10}$.

Zachowane źródła zdają się rzeczywiście potwierdzać narodziny Warcisława II dopiero w drugiej połowie lat trzydziestych, a może nawet na początku lat czterdziestych XIII w. Dowodem wcześniejszej daty narodzin nie może być przywilej dotyczący nadania Darłowa z datą 1205 r., który został uznany za falsyfikat z początków XIV w. powstały w związku z pretensjami biskupstwa kamieńskiego do dóbr w ziemi sławieńskiej. Najistotniejsze wydaje się stwierdzenie o dowolnym dobraniu osób występujacych w dokumencie, być może na podstawie innych autentycznych źródeł w celu osiagnięcia konkretnych korzyści ${ }^{11}$. Mniej jednoznaczny jest natomiast brak Warcisława II w autentycznej bulli protekcyjnej Grzegorza IX z $1231 \mathrm{r}$. Występowanie na powyższym dokumencie starszego z braci, Mściwoja II, tłumaczono bowiem osiągnięciem przez niego odpowiedniego wieku do udziału w wyprawach wojennych (18 lat) ${ }^{12}$ czy tylko w czynnościach prawnych (12 lat) ${ }^{13}$ bądź nawet przekroczeniem siódmego roku życia i przejściem wówczas pod opiekę ojca ${ }^{14}$.

\section{P 168, 177.}

8 E. Rymar, Sprawa pochodzenia Ermengardy, drugiej żony Świętopetka Gdańskiego, RG 1982, t. 42, z. 1, s. 5-14; idem, Rodowód..., s. 125-128, 137-139, 244-245, 274-275.

9 B. Śliwiński, Poczet..., s. 34, 53-54; idem, Mściwoj II..., s. 39-42.

10 M. Smoliński, Świętopetk..., s. 281.

11 P 13; A. Gut, Średniowieczna dyplomatyka wschodniopomorska: dokumenty i kancelarie Pomorza Wschodniego do 1309 r., Szczecin 2014, s. 266-267 (gdzie starsza literatura).

12 E. Bahr, Genealogie..., s. 40.

13 G. Labuda, Pomorze Wschodnie $w$ dobie utrwalania ustroju feudalnego (1230-1310) [w:] Historia Pomorza, t. I, cz. 1, red. idem, Poznań 1969, s. 529; idem, Mściwoj II [w:] PSB, t. 22, Warszawa-Wrocław-Kraków-Gdańsk, 1977, s. 228; K. Jasiński, Dzieje ziem świeckiej i nowskiej od schytku XII w. do 1309 r. [w:] Dzieje Świecia nad Wista i jego regionu, t. I, red. idem, Warszawa-Poznań-Toruń 1979, s. 124.

14 B. Śliwiński, Mściwoj II..., s. 43. 
Warcisław II mógł więc po prostu któregoś ze wskazanych kryteriów nie spełniać. Ponadto zdaniem B. Śliwińskiego objęcie papieska opieką właśnie Mściwoja II miało stanowić wczesny przejaw dążeń Świętopełka do zapewnienia sukcesji swojemu synowi, z pominięciem niewymienionych w bulli braci księcia gdańskiego - Sambora II i Racibora - co można dostrzec w późniejszych dokumentach ${ }^{15}$. Nieobecność stryjów Warcisława II tłumaczono także posiadaniem przez nich własnych dzielnic, co miało jednak raczej miejsce w późniejszym okresie ${ }^{16}$. Wspominała o nich natomiast, choć nie imiennie, wcześniejsza bulla papieska z 1227 r., pomimo że najpewniej byli jeszcze nieletni ${ }^{17}$. Wobec powyższego ponownie zastanawiałby brak Warcisława II w bulli papieskiej z $1231 \mathrm{r}$. Mimo wszystko wydaje się, że Świętopełk, dbając o interesy swojej linii, nie odmawiałby opieki papieskiej także drugiemu z synów i ewentualnemu następcy, nawet jeśli byłby on niemowlakiem. Stąd wnosić trzeba, iż w $1231 \mathrm{r}$. Warcisława II faktycznie nie było jeszcze na świecie.

Zachowane w stosunkowo niewielkiej liczbie dokumenty pomorskie aż do 1248 r. nie wymieniły Warcisława II $^{18}$. Młodszy syn Świętopełka nie występował także w źródłowych informacjach dotyczących wojny księcia gdańskiego ze swoimi młodszymi braćmi, zakonem krzyżackim i władcami piastowskimi toczonej w latach $1242-1248^{19}$. Nie jest to jednak okoliczność przesądzająca, bowiem właśnie ze względu na milczenie źródeł w powyższym okresie umieszcza się śmierć innego z synów Świętopełka, Jana, znanego tylko z jednej wzmianki w nekrologu oliwskim ${ }^{20}$. Nieobecność Warcisława II mogła także wynikać z charakteru, subiektywizmu i późniejszego czasu powstania źródeł,

15 B. Śliwiński, Stosunki polityczne księcia Świętopetka z braćmi Samborem II i Raciborem. Wygnania i powroty juniorów [w:] Kaci, święci, templariusze, red. idem, Malbork 2008 (,Studia z Dziejów Średniowiecza”, nr 14), s. 459-460, przyp. 7.

16 B. Śliwiński, Sambor II..., s. 44-60.

17 P 35.

18 P 54. O autentyczności zob. G. Labuda, Geneza miasta na „prawie lubeckim” $w$ Gdańsku, KHKM, 1981, z. 1, R. 29, s. 65-67; A. Gut, Średniowieczna dyplomatyka wschodniopomorska..., s. 118-119.

19 Ostatnio o tym konflikcie zob. B. Śliwiński, Stosunki polityczne księcia Świętopetka..., s. 506-527; idem, Sambor II, ksiażę tczewski, wyd. 2, Kraków 2015, s. 98-119; idem, Mściwoj II..., s. 50-61; M. Smoliński, Świętopetk..., s. 289-323. Tamże źródła z omówieniem.

20 Kwestia Jana pozostaje nierozstrzygnięta, zob. E. Rymar, Rodowód..., s. 275-276; B. Śliwiński, Poczet..., s. 52-53; idem, Mściwoj II..., s. 34-35, przyp. 9; M. Smoliński, Polityka zachodnia księcia gdańsko-pomorskiego Świętopetka, Gdańsk 2000, s. 80-82. 
szczególnie narracyjnych ${ }^{21}$. Ponadto wymieniały one głównie najważniejszych uczestników opisywanych wydarzeń. Wydaje się, że Warcisław II nie brał udziału w konflikcie. Dowodziłby tego szczególnie jego brak w pierwszym przywileju Świętopełka dla klasztoru w Darguniu wystawionym 22 września 1248 r. w Gdańsku, poświadczonym przez miejscowych urzędników i duchownych ${ }^{22}$. Równolegle toczyły się rozmowy pokojowe zakończone traktatem na Kowalowym Ostrowie 24 listopada tego roku. Młodszy syn Świętopełka pojawił się dopiero 2 grudnia 1248 r. w Słupsku, gdzie potwierdzał rozszerzenie nadania dla wspomnianych cystersów. Nasuwa się więc wniosek, że Warcisław II nie był dopuszczany do dotyczących konfliktu wydarzeń. Być może nawet nie przebywał na związanych $\mathrm{z}$ nimi terenach nadwiślańskich, lecz gdzieś dalej, choćby, jak sugeruje ostatni z wymienionych dokumentów, w Słupsku. Możliwość taką zdaje się wzmacniać hipoteza Marka Smolińskiego, według której wobec przedłużającej się niewoli Mściwoja II u Krzyżaków, mogącej się zakończyć nawet jego śmiercia, Świętopełk dopuszczał jako swego ewentualnego następcę na tronie księcia zwierzchniego właśnie Warcisława II. W takim wypadku umieszczenie go w oddalonym od działań wojennych Słupsku służyłoby zapewnieniu mu bezpieczeństwa, szczególnie jeśli był zbyt młody. Być może nawet na tyle, że nie został jeszcze oddany pod opiekę ojca. W takim wypadku mógł liczyć nawet mniej niż 7 lat $^{23}$. Nie przeczy temu kryterium wieku sprawnego dopuszczającego do udziału w czynnościach prawnych, który według Oswalda Balzera wynosił 12 lat. Jak wykazał bowiem Władysław Sobociński, aż do XIV w. żadnej takiej ścisłej granicy lat nie było, liczyło się tu jedynie osiagnięcie rzeczywistej dojrzałości. Tym bardziej nie miało to zastosowania wobec współwystawców, którymi były niejednokrotnie nawet kilkuletnie dzieci. Obecność młodego wiekiem księcia

21 M. Pollakówna, Kronika Piotra z Dusburga, Wrocław-Warszawa-Kraków 1968, s. 12, 38-49, 121, 145; T. Jasiński, Najstarsze kroniki i roczniki krzyżackie dotyczace Prus, Toruń 1996, s. 7-9, 12-17, 58-61, 69-83; J. Wenta, Kronika Piotra z Dusburga. Szkic źródłoznawczy, Toruń 2003, s. 58-72, 121-124; M. Smoliński, Świętopetk..., s. 289, 303-304. Warto zauważyć, że w Kronice Piotra z Dusburga Warcisław występuje tylko raz, w dodatku w błędnym kontekście, zob. Petrus de Dusburgk Chronica Terrae Prussae, oprac. J. Wenta i S. Wyszomirski [w:] MPH, s.n., t. XIII, Kraków 2007, s. 184-185; Piotr z Dusburga, Kronika ziemi pruskiej, tłum. S. Wyszomirski, oprac. J. Wenta, wyd. 2, Toruń 2004, s. 159-160.

22 P 108.

23 P 110-111, 112; B. Śliwiński, Mściwoj II..., s. 43, 58-61; M. Smoliński, Świętopetk..., s. 281. 
mogła wynikać jedynie z podniosłości i znaczenia samej czynności ${ }^{24}$. Odpowiada to domniemanym okolicznościom wystawienia przywileju 2 grudnia 1248 r. Niewykluczone także, że Warcisław II miał już więcej niż 7 lat, lecz ze względu na zawirowania dalej przebywałby pod opieką matki bądź innych osób.

Wzmianki zarówno o Warcisławie II, jak i Mściwoju II pojawiły się ponownie dopiero w dyplomie wystawionym według zawartej w nim datacji 5 kwietnia 1252 r. w Słupsku. Bracia potwierdzali tutaj poszerzenie nadania dla klasztoru w Darguniu na rzecz jego powstającej w Bukowie filii ${ }^{25}$. Dyplom ów uznaje się w literaturze za falsyfikat formalny, spisany w latach sześćdziesiątych lub osiemdziesiątych XIII w., być może na podstawie klasztornej zapiski. Za wiarygodna przyjmuje się informację o obecności synów Świętopełka i dokonanej przez nich czynności. Omawiany dokument mógł bowiem zostać spisany w związu z konfirmacjami dóbr klasztornych, dokonanymi w latach 1268-1269 zarówno przez Warcisława II, jak i jego brata, oraz w 1290 r. przez samego Mściwoja II. Mogli oni więc osobiście, w dodatku już jako władcy, zweryfikować prawdziwość doręczonych informacji ${ }^{26}$.

Zwraca uwagę obecność wszystkich członków rodziny, w tym szczególnie młodszego z synów oraz małżonki księcia, co tłumaczono uroczystym i rodowym charakterem dokonanego wtedy nadania, podobnie jak jego dość znaczną wartościa. Jako przyczynę tej ofiarności uznawano chęć rozwoju gospodarczego danego obszaru, w wyniku spodziewanej działalności cystersów. Błażej Śliwiński wskazał również, iż podobnie jak nadanie Bukowa z 1248 r. było formą dziękczynienia za uwolnienie Mściwoja II, tak jego poszerzenie cztery lata później miało uczcić małżeństwo pierworodnego syna Świętopełka z Judytą z rodu Wettynów, do czego według ustaleń M. Smolińskiego doszło najprawdopodobniej właśnie przed kwietniem 1252 r. Ponadto

24 O. Balzer, Genealogia Piastów, wyd. 2, Kraków 2005, s. 38-39; W. Sobociński, Historia rzadów opiekuńczych w Polsce, CPH 1949, t. 2, s. 248-251; E. Rymar, Rodowód..., s. 27-28.

25 P 135: „quod nos de voluntate et consensu dilectissime collateralis nostre Ermegardis ac dilectorum Mestwini et Wartislai filiorum nostrorum”.

26 A. Gut, Dokumenty dla klasztoru w Bukowie Morskim do 1316 roku, ZH 2008, t. 73, z. 1, s. 104-111; eadem, Średniowieczna dyplomatyka wschodniopomorska..., s. 279; B. Popielas-Szultka, Rozwój gospodarczy dominium bukowskiego od połowy XIII do połowy XVI wieku, Słupsk 1980, s. 15-16, 23-24, 29-30, 32-33, 39; eadem, Spostrzeżenia o cysterskich skryptoriach i dokumentach, „Słupskie Studia Historyczne” 2012, nr 18, s. 333-336. 
fundacja klasztoru w ziemi sławieńskiej podkreślałaby władzę Sobiesławiców na tym obszarze. Wtedy właśnie zaczął narastać o nią spór z rządzacymi na Pomorzu Zachodnim Gryfitami ${ }^{27}$. Oficjalny konsens Warcisława II w powyższym wypadku na nadanie nie musiał więc potwierdzać osiagnięcia przez niego wieku sprawnego. Tym bardziej że już wcześniej na Pomorzu Wschodnim do tego typu czynności dopuszczano nieletnich, choćby w wypadku fundacji klasztoru w Stołpie-Żukowie z 1212 r., na która zgody udzielali także młodsi synowie Mściwoja I. Następnie powtarzali ją w 1224 r., prawdopodobnie wciąż nie osiagnąwszy dorosłości ${ }^{28}$.

Szczególnie istotna jest także nieobecność Warcisława II w dokumentach kończących konflikt, wystawionych na przełomie lipca i sierpnia 1253 r., pomimo że występowało w nich wielu dostojników świeckich i Mściwoj II ${ }^{29}$. Znów można więc przypuszczać, że młodszy syn Świętopełka wciąż nie był w wieku pozwalającym na udział w walce. Być może nawet przebywał poza dworem ojca.

Kolejną wskazówką pomagająca określić wiek Warcisława II jest przekaz Rocznika kapituły poznańskiej, informujący o jego udziale w przypadającej na 1256 r. drugiej fazie wojny Sobiesławiców z Przemysłem I i Kazimierzem Kujawskim o Nakło. Według rocznikarza w Wielki Piątek, czyli 24 kwietnia tego roku, pod sporny gród przybył książę Świętopełk z synami i bratem. Powyższe informacje powtórzyła powstała jeszcze w XIII lub XIV w. Kronika wielkopolska ${ }^{30}$. Choć wspomniani synowie zostali tutaj podani bez imion, można uznać ich za Mściwoja II i Warcisława II, gdyż występowali w dokumentach Świętopełka z tego okresu. Podobnie obecnego pod Nakłem ich stryja identyfikuje się z Raciborem, księciem białogardzkim - Sambora wykluczono z powodu ciagle złych

27 M. Smoliński, Polityka..., s. 155-210; idem, Świętopetk..., s. 281-283; B. Śliwiński, Gdzie znajdowała się pierwsza dzielnica księcia Mściwoja II wschodniopomorskiego [w:] A Pomerania ad ultimas terras. Studia ofiarowane Barbarze Popielas-Szultce w sześćdziesiata piata rocznice urodzin i czterdziestolecie pracy naukowej, red. J. Sochacki, A. Teterycz-Puzio, Słupsk 2011, s. 59; idem, Mściwoj II..., s. 64-68.

$28 \quad \mathrm{P} 14,26$.

29 P 153, 154, 155.

30 Rocznik kapituly poznańskiej [w:] MPH, s.n., t. VI, oprac. B. Kürbis, Warszawa 1962, s. 36-37: „Item eodem anno in Quadragesima dux Swanthopelcus cum filiis suis et cum fratre suo [...] ad antiquam Nakel expensa [ivit]. [...] In hoc eidem duci Swanthopelci [...] de filiis nobilium suorum tradidit ei novem obsides [...]"; Kronika wielkopolska [w:] MPH, s.n., t. VIII, wyd. B. Kürbis, Warszawa 1970, s. 102-105, 181-182, przyp. 620-633; Kronika wielkopolska, tłum. K. Abgarowicz, oprac. B. Kürbis, wyd. 2, Kraków 2010, s. 173-177. 
stosunków z najstarszym bratem. Wiarygodności przekazu nie podważa, a nawet może wzmacnia, podkreślany subiektywizm jej autora, współczesnego opisywanym wydarzeniom, który dążył do ukazania w jak najlepszym świetle książąt piastowskich i pomniejszenia sukcesów Pomorzan ${ }^{31}$. Warcisław musiał tym samym osiagnać już pewna dojrzałość fizyczna, skoro dowodnie brał udział w walce. Jednak i tutaj brakowało dokładnego kryterium wieku. Wiadomo, że Bolesław Krzywousty towarzyszył wyprawom wojennym, majac zaledwie 6 lub 7 lat, zaś w pełni w nich uczestniczył, będąc 12-, 13-latkiem. Współczesny synom Świętopełka Przemysł II dowodził na wojnie już w wieku 16 lat. Warcisław II prawdopodobnie też miał tyle lat. Jego udział w działaniach w Wielkopolsce byłby więc co najmniej wdrożeniem w obowiązki władcy, bądź tylko wojownika, lub czynem już człowieka dorosłego ${ }^{32}$. Niemniej wzmianka o udziale w wyprawie na Nakło, w połączeniu z zaznaczoną wyżej nieobecnością Warcisława II w źródłach, pozwala kłaść narodziny tego księcia raczej na drugą połowę lat trzydziestych, a nawet początek lat czterdziestych XIII w.

\section{II}

Znając w przybliżeniu datę osiagnięcia przez Warcisława II pełnoletności, należy przejść do próby określenia jego pozycji wewnątrz państwa i dynastii Sobiesławiców za życia ojca. Jak dotąd problemem tym zajmowano się głównie w przypadku Mściwoja II. Dawniej dość powszechnie uznawano, iż to właśnie on został wyznaczony przez Świętopełka na przyszłego księcia zwierzchniego. Świadczyłoby o tym eksponowanie go w dokumentach u boku władcy Gdańska już od 1231 r., szczególnie dotyczących spraw zewnętrznych. W 1248 r. Mściwoj II udzielił zgody na ustalenia zawartego wtedy pokoju z Krzyżakami i zobowiązał się do ich przestrzegania w przyszłości. Pięć lat później nie tylko powtórzył te zapewnienia,

31 O wojnie nakielskiej 1255-1256 r. i jej obrazie w źródłach: B. Śliwiński, Wojna o Nakło między księciem wschodniopomorskim Świętopetkiem a księciem poznańskim Przemystem I $i$ okolicznościach zawarcia pokoju w Kcyni z lipca 1256 r. [w:] In tempore belli et pacis. Ludzie - Miejsca - Przedmioty. Ksiega pamiatkowa dedykowana prof. dr hab. Janowi Szymczakowi w 65-lecie urodzin i 40-lecie pracy naukowo-dydaktycznej, red. T. Grabarczyk, A. Kowalska-Pietrzak, T. Nowak, Warszawa 2011, s. 486-494; idem, Mściwoj II..., s. 68-74, 79-80.

32 S. Rosik, Bolestaw Krzywousty, Wrocław 2013, s. 73-79; B. Nowacki, Przemyst II. Odnowiciel korony polskiej (1257-1296), wyd. 2, Kraków 2007, s. 57, 64-65. 
ale także był współwystawcą przywileju dla lubeczan. Te ostatnie dokumenty zgodnie przyjmuje się także za dowód uzyskania przez Mściwoja II własnej dzielnicy, o czym niżej ${ }^{33}$. Możliwości takiej nie wykluczano również w wypadku Warcisława II. Wiązano to jednak dopiero z układem w Kamieniu z 1264 r. i narastającym konfliktem wewnątrz dynastii.

Tymczasem wskazówkę do określenia pozycji Warcisława II można odnaleźć już w pierwszym wymieniajacym go dokumencie z 2 grudnia 1248 r. Marek Smoliński zwrócił uwagę, iż obaj synowie Świętopełka zostali w nim nazwani spadkobiercami, co - jak wspomniano - uznał za przejaw przygotowywania Warcisława do roli ewentualnego następcy. Po powrocie Mściwoja książę gdański nie miał jednak ostatecznie zdecydować, któremu z synów przypadnie po jego śmierci funkcja księcia zwierzchniego ${ }^{34}$. Nie odrzucając powyższej możliwości, określenie zarówno Mściwoja II, jak i Warcisława II spadkobiercami, mogło po prostu oznaczać, iż obaj potomkowie byli uprawnieni do otrzymania odpowiedniego działu ze spadku po swoim ojcu, zgodnie ze spotykaną w epoce rozbicia dzielnicowego zasadą dziedziczenia. Jej funkcjonowanie na Pomorzu Wschodnim przyjmuje się w oparciu o informacje dotyczące sporu Świętopełka ze swoimi braćmi - Samborem II i Raciborem, którzy domagali się od księcia gdańskiego równego podziału ziemi, powołując się na obowiąujące prawo. Ponadto, zgodnie z tzw. relacją Marolusa, ojciec wymienionych - Mściwoj I - polecił Świętopełkowi, aby przekazał Samborowi wyznaczona mu już dzielnicę, gdy ten ukończy 20. rok życia. W zamian Sambor miał być we wszystkim posłuszny starszemu bratu. Wskazuje to więc także na stosowanie zasady senioratu. Pomimo, jak wskazywano, chęci uszczuplenia pozycji braci i umocnienia swojej władzy księcia zwierzchniego, nie ma powodów, by twierdzić, że Świętopełk nie chciał stosować powyższych zasad $\mathrm{w}$ odniesieniu do swoich synów ${ }^{35}$.

W świetle poczynionych wyżej ustaleń na temat daty narodzin Warcisława II, można wnioskować, że nie otrzymał swojej dzielnicy już w 1248 r., gdyż z dużym prawdopodobieństwem nie osiagnął jeszcze wtedy uprawniającego do tego wieku 20 lat. Również w wypadku

33 P 111, 151-153. Starsze poglądy zob. B. Śliwiński, Gdzie znajdowała się pierwsza dzielnica..., s. 44-55; idem, Mściwoj II..., s. 59-60; M. Smoliński, Świętopetk..., s. 272-273; zob. także przyp. 35 i 50.

${ }_{34}$ M. Smoliński, Świętopetk..., s. 281.

35 P 113; B. Śliwiński, Stosunki polityczne księcia Świętopetka..., s. 457-464. 
Mściwoja wskazano, iż doszło do tego dopiero w 1252 r. i to w związku ze wspomnianym małżeństwem z Judytą z rodu Wettynów. Uzyskania własnej dzielnicy dowodziłaby wspomniana pozycja Mściwoja odnotowana w dokumentach z 1253 r., zupełny brak jego imienia w późniejszych dyplomach ojca oraz fakt, iż w 1264 r. tytułował się księciem w Świeciu nad Wisłą. Tam też według dawniejszych opinii mógł rządzić już wcześniej, niewykluczone, że początkowo jedynie w imieniu Świętopełka, który jeszcze w 1260 r. występował tutaj jako władca $^{36}$. Jednak B. Śliwiński, m.in. z powyższego względu wskazał, że pierwszą dzielnica Mściwoja była ziemia raciąsko-szczycieńska. W obu próbach lokalizacji, co warto odnotować, jednym z argumentów położenia władztwa Mściwoja w południowej części państwa było przeprowadzenie przez niego w $1255 \mathrm{r}$. wyprawy na położone blisko pomorskiej granicy, ale leżące już w Wielkopolsce Nakło ${ }^{37}$.

Wobec powyższego w kwestii Warcisława II jest istotne, co podkreślał już E. Rymar, że młodszy z synów Świętopełka w początkowym okresie pojawiał się tylko w dokumentach wystawionych w Słupsku i dotyczących ziemi sławieńskiej. Teorię wspomnianego badacza o związkach Warcisława II z tym terenem, bądź ogólniej zachodnimi obszarami państwa, może wzmacniać kolejna hipoteza M. Smolińskiego. Historyk ten wskazał na możliwość funkcjonowania także wśród Sobiesławiców wzoru wychowania spotykanego na dworach południowego wybrzeża Bałtyku, także w północnych Niemczech. Młodzi ksiązęta przebywali tam w swoich przyszłych dzielnicach, oswajając się z nimi i kształcąc pod opieką wyznaczonych przez ojca urzędników. Korzystanie z tego rozwiązania na Pomorzu Wschodnim poświadczałyby informacje płynące z falsyfikatu dokumentu Świętopełka datowanego na 1229/1230 r., w którym raczej jeszcze nieletni wtedy Sambor II został przypisany do Lubiszewa nad Wisła, a Racibor miał tytuł książęcy. Zdaniem powyższego badacza fałszerz nie dopuściłby się tak dużego nadużycia, dlatego przytoczone wzmianki mogą oddawać prawdę ${ }^{38}$. Podobna sytuacja mogłaby więc spotkać także Warcisława II. Tłumaczyłoby to jego nieobecność w dokumentach zarówno z 1248, jak i z 1253 r., wystawionych na Kowalowym Ostrowie i w Świeciu, czyli na południowo-wschodnich obszarach

36 G. Labuda, Mściwoj II..., s. 229; K. Jasiński, Dzieje ziem świeckiej i nowskiej..., s. $124-125$, zob. przyp. 51 .

37 B. Śliwiński, Gdzie znajdowata się pierwsza dzielnica..., s. 44-55.

38 P 39; M. Smoliński, Świętopetk..., s. 242-244. 
państwa. Nie przeczy to przytoczonej wyżej hipotezie o dopuszczeniu około 1248 r. Warcisława II do roli ewentualnego następcy. Ponadto mógłby on przebywać pod opieka matki, na co wskazywałaby obecność na dokumencie z 1252 r. imienia Ermengardy. Na uznanie ich pokrewieństwa pozwalają bowiem dość przekonywające wnioski badaczy umieszczających ślub wspomnianej księżniczki ze Świętopełkiem około 1236 r. Należy jednak zaznaczyć, iż przytaczane w powyższej kwestii argumenty maja głównie charakter pośredni ze względu na brak jednoznacznych wzmianek ${ }^{39}$. Przypomnieć trzeba choćby fakt wystapienia Ermengardzie w źródłach u boku Świętopełka dopiero, i to jedyny raz, właśnie w 1252 r.

Pewne wnioski na temat statusu Warcisława II może przynieść również przekaz o jego udziale w wojnie o Nakło. Zwrócono w literaturze uwagę, iż Mściwoj II wystapił w nim z tytułem książęcym, podczas gdy niewymieniony z imienia Warcisław II został określony jako syn. Miałoby to stanowić kolejny dowód uzyskania przez starszego z braci własnej dzielnicy. Równie dobrze, jak wskazał B. Śliwiński, owa tytulatura mogła wynikać jedynie z faktu pokrewieństwa z księciem gdańskim oraz wielkopolskiego pochodzenia autora nieznającego dokładnych relacji między Sobiesławicami ${ }^{40}$. Warto jednak wskazać, że Warcisław II pojawił się pod Nakłem dopiero w drugiej fazie konfliktu razem z ojcem i stryjem, podczas gdy Mściwoj II, również obecny w powyższym gronie, atakował sporny gród już wcześniej. Mogłoby to nie tylko potwierdzać samodzielność starszego z braci, ale także sugerować, iż Warcisław przebywał stale w północnej części państwa. Jest jednak wątpliwe, by już wtedy objął własną dzielnicę, nawet gdyby osiagnął wiek 20 lat. Do takiego wniosku skłania przykład wspomnianego Racibora, który choć w latach pięćdziesiątych XIII w. oficjalnie był księciem w Białogardzie nad Łeba, to najpewniej stale przebywał w otoczeniu Świętopełka, w tym czasie bowiem często poświadczał jego dokumenty. Mogło to więc w 1256 r. dotyczyć także i Warcisława.

Podobne rozwiąanie stosowano na ówczesnym dworze mazowieckim. Siemowit I, najmłodszy z żyjących synów Konrada Mazowieckiego, występował u boku ojca aż do jego śmierci w 1248 r., choć osiagnął już wiek 23-24 lat. Ponadto od 17. roku życia był współwystawca

39 Uzasadnienie i starsze poglądy zob. M. Smoliński, Polityka..., s. 73-90; idem, Świętopetk..., s. 187-201.

40 M. Smoliński, Świętopetk..., s. 283-284; B. Śliwiński, Mściwoj II..., s. 69, przyp. 31. 
licznych dyplomów. Kazimierz Jasiński, dostrzegając to podobieństwo, uznał nawet, że Warcisław II, podobnie jak Siemowit I, najpierw miał przebywać u boku ojca, a następnie otrzymać po nim najważniejszą dzielnicę, czyli gdańska, o czym niżej ${ }^{41}$.

Dalsze przebywanie Warcisława na dworze ojca potwierdzałaby wzmianki o nim w dokumentach Świętopełka z 1257 i 1259 r. Pełne przyjęcie tego wniosku utrudnia jednak uznawanie powyższych dyplomów za falsyfikaty. Pierwszy z nich spisano w związku z poczynionym 27 lipca 1257 r. w Białogardzie nad Łebą nadaniem wsi Wierzchucino na rzecz klasztoru cysterek w Żarnowcu. Zgody na nie udzielił Racibor, prawdopodobnie jako oficjalny władca dzielnicy, której terenu ono dotyczyło, oraz Mściwoj II i Warcisław II, wymienieni również na liście świadków ${ }^{42}$. Przyjęto, iż powyższy dokument spisano dopiero na przełomie lat siedemdziesiątych i osiemdziesiątych XIII w. albo nawet około 1305 r., być może w oparciu o oryginalny dyplom lub klasztorną zapiskę. Dzięki temu byłaby dopuszczalna autentyczność listy uczestniczących w nadaniu osób. Jednak obecność Warcisława byłaby niemal pewna tylko wtedy, gdyby falsyfikat niewatpliwie powstał jeszcze za życia jego brata, który mógłby zweryfikować zawarte w nim informacje. W wypadku spisania dokumentu dopiero w XIV w. należałoby dopuścić możliwość, że wymienienie jednego z panujących wcześniej na Pomorzu książąt było celowe i służyło dodatkowemu uwiarygodnieniu dokumentu ${ }^{43}$.

Z kolei dokument z 1259 r. należy do grupy czterech dyplomów dotyczacych nadania Ręboszewa klasztorowi norbertanek w Zuukowie, których wzajemna filiacja i autentyczność pozostaje dyskusyjna ${ }^{44}$. Dotyczy to również omawianego aktu pozbawionego daty dziennej,

41 J. Spors, Podziały administracyjne Pomorza Gdańskiego i Stawieńsko-Stupskiego od XII do poczatku XIV w., Słupsk 1983, s. 284-286; B. Śliwiński, Ksiażę białogardzki Racibor, „Biuletyn Historyczny Lęborskiego Bractwa Historycznego i Muzeum w Lęborku" 2003, nr 21, s. 38-41; K. Jasiński, Gdańsk w okresie samodzielności politycznej Pomorza Gdańskiego [w:] Historia Gdańska, t. I, red. E. Cieślak, Gdańsk 1978, s. 274-275; A. Wajs, Siemowit I-przy ojcu Konradzie Mazowieckim - rola mtodego księcia na dworze piastowskim, „Miscellanea Historico-Archivistica” 1994, t. IV, s. $6-12$.

42 P 168: „cum consensu fratris nostri Raciborii et filiorum nostrorum Mistwini et Warzlaui [...]. Testes sunt: Mistwin et Warzlaus filii nos tri”.

43 A. Gut, Średniowieczna dyplomatyka wschodniopomorska..., s. 231-240, 282-283; B. Śliwiński, Gdzie znajdowała się pierwsza dzielnica..., s. 47, przyp. 17; idem, Mściwoj II..., s. 69 przyp. 31; M. Smoliński, Świętopełk..., s. 283.

${ }_{44}$ P 142 (1252), 167 (26 VII 1257), 174 (26 VII 1258), 177 (1259). 
lecz podającego jako miejsce wystawienia Żukowo. Jako jedyny z całej grupy wymienił także Warcisława, Mściwoja i Racibora udzielających zgody na nadanie dwóch wsi ${ }^{45}$. Wcześniejsi badacze uznawali omawiany dokument za autentyk, obecnie jednak przeważa opinia o jego fałszerstwie. Według Agnieszki Gut omawiany dyplom posłużył do sporządzenia dokumentu z 1257 r., który uznała za autentyczny i przesunęła datę jego powstania na 1262 r., czego dowodziłoby przepisanie występujących w $1259 \mathrm{r}$. świadków. Pominięto przy tym osoby pozostałych książąt, co w przypadku Racibora badaczka tłumaczy opuszczeniem przez niego dzielnicy białogardzkiej. Należy zaznaczyć, że stanowiąca tutaj przesłankę kwestia końca rządów Racibora pozostaje sporna, co w pewien sposób osłabia powyższą teorię. Przyjęcie jej mogłoby potwierdzać nieprawdziwość wzmianki o obecności książąt przy nadaniu z $1259 \mathrm{r}$. Należy więc częściowo się zgodzić ze zdaniem M. Smolińskiego, iż w oparciu o powyższy dokument nie można wysuwać pewnych wniosków na temat ówczesnej pozycji synów Świętopełka. Powołanie się na obu synów mogło świadczyć o tym, że zarówno Mściwoj, jak i Warcisław byli traktowani przez współczesnych lub potomnych jako równoprawni spadkobiercy Świętopełka ${ }^{46}$.

Odtworzenie dokładnych losów Warcisława II w kolejnych latach utrudnia brak wzmianek o nim do 1264 r., co dotyczy także Mściwoja II. Jedynie w 1263 r. Świętopełk wspomniał ogólnie o swych nieobecnych spadkobiercach, którzy nie mogą unieważnić dokonanego wtedy nadania dla klasztoru oliwskiego ${ }^{47}$. Sytuacja ta może po prostu wynikać ze skromności źródeł.

Warcisław II wspomniany został dopiero w dokumencie Mściwoja II wystawionym 20 września 1264 r. w Kamieniu Pomorskim na Pomorzu Zachodnim. Starszy syn Świętopełka przekazywał w nim na własność Barnimowi I i jego ewentualnym następcom posiadaną dzielnicę świecka, której księciem się tytułował, zachowując jednak prawo do jej dożywotniego posiadania. Ponadto władca

45 P 177: „de assensu et bona voluntate fratris mei Ratiborii ac filiorum meorum Mistuii et Wartislai”.

${ }_{46}$ P 186; A. Gut, Autentyczność trzynastowiecznych dokumentów klasztoru norbertanek $w$ Żukowie [w:] Scriptura, diploma, sigillum. Prace ofiarowane profesorowi Kazimierzowi Bobowskiemu, red. J. Zdrenka, J. Karczewska, Zielona Góra 2009; eadem, Średniowieczna dyplomatyka wschodniopomorska..., s. 280, 284-285, 286-287; M. Smoliński, Świętopetk..., s. 283. Ostatnio o Raciborze zob. B. Śliwiński, Mściwoj II..., s. 108-112.

47 P 202: „ne a nostris succesoribus vel ab aliquibus predicta emptio et consensio possit in posterum irritar"i. 
Pomorza Zachodniego miał przejaćc dobra i terytoria, które Mściwoj odziedziczyłby po swoim ojcu i bracie ${ }^{48}$. Osobiście Warcisław II wystapił w Sławnie 21 sierpnia 1265 r., otwierając listę świadków nadania Świętopełka dla klasztoru w Bukowie. Został przy tym dodatkowo określony jako „najukochańszy syn”. Zabrakło natomiast wzmianki o Mściwoju II ${ }^{49}$.

Historycy starali się na różny sposób wyjaśnić znaczenie pierwszego z dokumentów, zwanego w literaturze układem w Kamieniu. Zawarty na jego mocy sojusz Mściwoja II z Barnimem I według dawniejszych poglądów mógł być skierowany przeciwko Rugii, Krzyżakom lub Samborowi II ${ }^{50}$. Najprawdopodobniej był jednak wymierzony w Świętopełka i Warcisława II, gdyż to oni, a nie kto inny, zostali wymienieni w treści układu. Zaś wśród domniemanych przyczyn oczywistego buntu Mściwoja II najczęściej wskazywano na dokonane niewiele wcześniej lub równocześnie, bądź nawet dopiero zamierzone, wydzielenie przez Świętopełka dzielnicy gdańskiej Warcisławowi II, a nie swemu pierworodnemu. Świadczyłyby o tym nie tylko jego późniejsze rządy w Gdańsku, ale także pozycja Warcisława II w dokumencie z 1265 r., która byłaby przejawem faworyzowania tego księcia przez ojca ${ }^{51}$. Niektórzy łączyli z tym utratę przez Mściwoja II pozycji księcia zwierzchniego. Powyższa decyzję Świętopełka tłumaczono chęcią utrzymania jedności politycznej Pomorza, wcześniejszymi niesnaskami z Mściwojem lub innymi przyczynami natury politycznej. Jak sądził Jan Powierski, Świętopełk uczynił tak ze względu na zagrożenie ze strony zakonu krzyżackiego. Chciał mianowicie w ten sposób zapobiec realizacji zapisów traktatu z 1253 r., na mocy którego Krzyżacy w razie ewentualnego konfliktu mogli przejaćc na własność ziemię gdańska. Warcisław II natomiast w przeciwieństwie do Mściwoja II nie poświadczał zapisów tego traktatu, dzięki czemu wyznaczenie go na przyszłego księcia gdańskiego mogło pod względem

48 P 206; B. Śliwiński, Mściwoj II..., s. 83-84.

49 P 208: "dilectissimus filius meus Wartislaus"

50 J. Powierski, Układ kamieński (1264) na tle stosunków między ksiażętami Pomorza, Krzyżakami i Prusami w latach sześćdziesiatych XIII wieku, „Rocznik Olsztyński” 1968, t. 8, s. 11-31 (gdzie starsze poglądy).

51 K. Jasiński, Gdańsk w okresie..., s. 275-276, 283-284; idem, Dzieje ziem świeckiej i nowskiej..., s. 124-126; K. Zielińska, Zjednoczenie Pomorza Gdańskiego z Wielkopolska pod koniec XIII wieku. Umowa Kepińska 1282 r., RTNT 1968, r. 73, z. 3, s. 18-19; B. Włodarski, Świętopełk i Mściwoj II (Z dziejów Pomorza Gdańskiego w XIII wieku), ZH 1968, t. 33, z. 3, s. 78-81; G. Labuda, Mściwoj II..., s. 129; idem, Historia Kaszubów w dziejach Pomorza, cz. 1: Średniowiecze, Gdańsk 2006, s. 245-246. 
prawnym osłabić pretensje Krzyżaków ${ }^{52}$. Dopuszczano jednak także, jak czynili to m.in. Gerard Labuda i Józef Spors, iż Świętopełk nie dokonał przed śmiercia formalnego podziału kraju lub uczynił to w sposób niejasny. Zgodził się z tym B. Śliwiński, wskazując, że nic nie potwierdza istnienia planów wspomnianego księcia co do przyznania Gdańska Warcisławowi, jak i zwierzchnich rządów Mściwoja po 1266 r. Badacz jako przyczynę konfliktu między ojcem i synem wskazał brak wspólnego zdania co do polityki pruskiej ${ }^{53}$, M. Smoliński zwrócił zaś uwagę na przekaz Kroniki oliwskiej, według której Warcisław II przejął rządy w Gdańsku dopiero po śmierci ojca i to w wyniku decyzji „Pomorzan”, czyli najprawdopodobniej możnych ${ }^{54}$.

Dla wyjaśnienia statusu Warcisława II warto jeszcze raz zwrócić uwagę na zapisy układu w Kamieniu. Mściwoj darował Barnimowi tereny, „które moga nam przypaść albo zostać przekazane przez naszego ojca i przez brata" ${ }^{55}$. Jak widać Świętopełk i Warcisław II zostali wyraźnie rozróżnieni. Wydaje się, że postawienie obok siebie obydwu książąt w kontekście kwestii spadkowych miało konkretne znaczenie. Mogło ono oznaczać choćby wcześniejsze wyznaczenie Warcisława II przez Świętopełka na przyszłego księcia zwierzchniego. Jak wspomniano, zdaniem historyków wcześniej rolę tą miał pełnić Mściwoj II. Jednak z okresu po 1253 r., z którego pochodzą ostatnie mogace to potwierdzać przesłanki, brakuje dalszych dowodów co do wyznaczenia Mściwoja II na seniora. Mogłoby to jednak równie dobrze potwierdzać teorię o braku decyzji Świętopełka w tej sprawie.

Równocześnie z uznaniem Warcisława II za swego następcę Świętopełk mógł przyznać mu dzielnicę gdańska. Wątpliwości budziłby wspomniany przekaz Kroniki oliwskiej. W jego świetle Warcisław II mógł objąc rządy w Gdańsku nie w wyniku wcześniejszych ustaleń, a w związku z wydarzeniami mającymi miejsce

52 J. Powierski, Układ kamieński..., s. 12-13.

53 G. Labuda, Pomorze w okresie... [w:] Historia Pomorza, t. I, cz. 1, s. 529; J. Spors, Podziały administracyjne..., s. 287-288; B. Śliwiński, Rola polityczna możnowładztwa na Pomorzu Gdańskim w czasach Mściwoja II, Gdańsk 1987 s. 62-66; idem, Mściwoj II..., s. 82-99, 102-104.

54 Chronica Olivensis auctore Stanislao Abbate Olivensi [w:] MPH, Kraków 1893, t. VI, s. 313; M. Smoliński, Świętopetk..., s. 286-288, 332-333.

55 P 206: „donamus terras, castra, civitates, villas, et universa dominia, que ad nos devolvi poterunt vel devolverunt a patre nostro et a fratre”, cyt. za: B. Śliwiński, Mściwoj II..., s. 82. 
już po śmierci Świętopełka, w dodatku z poparciem „Pomorzan”. Ponadto Warcisław II nie pojawił się w dyplomach wystawionych w stołecznym grodzie w 1263 r. Można nawet zasugerować, iż nieobecność obydwu synów przy dokonanym wtedy nadaniu dla Oliwy, którym w dodatku zabroniono cofnięcia przywileju, była przejawem konfliktu wewnętrznego, w którym początkowo niejednoznaczną rolę odgrywał także Warcisław ${ }^{57}$. Omawiany zapis układu w Kamieniu byłby równie dobrze przejawem posiadania przez Warcisława dzielnicy na innym obszarze (tłumaczyłoby to jego pomijanie w źródłach z lat 1260-1263). Bardzo możliwe, że znajdowała się ona w ziemia sławieńskiej (do której dziedziczne prawa posiadała matka Warcisława II Ermengarda) lub - co bardziej prawdopodobne - ziemia słupskiej. Tam bowiem Warcisław przebywał w okresie swej młodości i stamtąd najprawdopodobniej pochodzili jego późniejsi współpracownicy ${ }^{58}$. W poszukiwaniu dzielnicy Warcisława nie można wykluczyć żadnej części państwa wschodniopomorskiego z wyjątkiem dzielnic ojca i brata, ale także ziemi białogardzkiej. W 1264 r. Mściwoj II nie mógł jej bowiem ofiarować Barnimowi I (jako posiadłości młodszego brata), skoro pięć lat później na mocy układu w Choszcznie przekazał ją na własność margrabiom brandenburskim ${ }^{59}$. Żadne inne przesłanki nie wskazuja jednak na posiadanie przez Warcisława II własnej dzielnicy przed 1266 r. Nie zachował się choćby ślad, także z późniejszego okresu, by podobnie jak Mściwoj II Warcisław II wstapił w związek małżeński, co ułatwiałoby uzyskanie uposażenia ${ }^{60}$. Nie został także określony księciem, do czego okazja była choćby w dokumencie

56 Chronica olivensis..., s. 313: „[...] Wardslaum iuniorem, quem Pomerani primo in dominio habere voluerunt [...]"; Kronika Oliwska. Źródto do dziejów Pomorza wschodniego z połowy XIV wieku, tłum. D. Pietkiewicz, oprac. B. Śliwiński, Malbork 2008 , s. 74.

$57 \quad \mathrm{P} 202$.

58 O otoczeniu Warcisława zob. B. Śliwiński, Rola polityczna możnowładztwa..., s. 23-45; idem, O kasztelanie stawieńskim Witku, urzędnikach pomorskich i zjeździe w Nakle, „Rocznik Słupski” 1990-1991, s. 114-131; J. Spors, Jeszcze o roli politycznej możnowładztwa na Pomorzu Gdańskim w czasach Mściwoja II, „Rocznik Słupski” 1990-1991, s. 132-148.

59 B. Śliwiński, Układ księcia wschodniopomorskiego Mściwoja II z margrabiami brandenburskimi w Choszcznie w 1269 r. Powrót problemu [w:] Mieszczanie, wasale, zakonnicy, red. idem, Malbork 2004 („Studia z Dziejów Średniowiecza”, nr 10), s. 267-285; idem, Mściwoj II..., s. 116-127.

60 Zdania nowożytnych historyków, uznających Warcisława za zięcia Siemowita I mazowieckiego, stanowią oczywistą pomyłkę, zob. O. Balzer, Genealogia ..., s. 583-586, 749, tabl. VII; E. Rymar, Rodowód..., s. 275. 
z 1265 r., gdzie, jak wskazał M. Smoliński, Warcisław II nazywany był wciąż synem, choć „najukochańszym”. Ostatnia z przesłanek może także, choć nie musi, zaprzeczać wyznaczeniu go na następcę Świętopełka, bowiem w dokumentach z 1253 r. także Mściwoj II nie występował z powyższym tytułem. W najgorszym wypadku informacja z $1264 \mathrm{r}$. byłaby jedynie kolejnym świadectwem posiadania w przyszłości przez Warcisława prawa do spadku po ojcu. W takim wypadku podział Pomorza Wschodniego rozstrzygnąłby się już po śmierci Świętopełka. Warcisław II mógł objąć rządy w Gdańsku jedynie w wyniku przebywania u boku ojca lub, co poświadczają źródła, decyzji możnych.

\section{III}

W świetle powyższych ustaleń Warcisław II osiagnąłby wiek sprawny niedługo przed 1256 r., gdy wziął udział w wojnie o Nakło. Niewykluczone, że przynajmniej częściowo był wcześniej wychowywany poza dworem ojca, pojawiał się wówczas bowiem wyłącznie w Słupsku. Niemniej, zarówno w tym, jak i późniejszym okresie Warcisława II traktowano jako prawnego spadkobiercę Świętopełka, podobnie jak jego starszego brata Mściwoja II. Świadczą o tym określenia i tytuły przydawane obu braciom. Zapisy układu w Kamieniu z 1264 r. pozwalaja także przypuszczać, iż Warcisław II jeszcze za życia ojca objął własną dzielnicę lub został wyznaczony przez Świętopełka na przyszłego księcia zwierzchniego bądź tylko władcę Gdańska. Równie możliwy jest jednak brak decyzji Świętopełka w tej sprawie i objęcie przez Warcisława II dzielnicy gdańskiej w wyniku decyzji możnych.

\section{Abstract}

\section{Date of Birth and Position of the Later Duke of Gdańsk, Wartislaw II, until 1266}

The paper is dedicated to the date of birth of Wartislaw II, Duke of Gdańsk in the years 1266-1269/70, and his position in the country, as well as the Samborides dynasty before they came to power. Most historians place the birth of Wartislaw II around 1236. The above conclusion seems to be supported by the fact that the sources clearly ignore this Duke until 1248, but also after that. Achieving a certain level of maturity 
is confirmed only by the very probable participation of Wartislaw II in the battle of Nakło in 1256. It is possible that he was raised outside the capital Gdańsk, namely in Słupsk, as we know that he spent time there in his youth (in 1248 and 1253). It may have been related to the possibility raised in literature of Swietopelk preparing Wartislaw II to become his successor, in place of Mestwin II, taken hostage by the Teutonic Order. It is possible, moreover, that Wartislaw II was making preparations there to take rule over his own province, as modelled after North-German solutions.

The above conclusions seem to be confirmed by the fact that since his youngest years, Wartislaw II was treated in documents as equal with Mestwin II - as Swietopelk's successor. It is evidenced by the titulature of both brothers and the presence of their names side by side in the documents. Such position entitled Wartislaw to take possession of his own province. Its acquisition in 1266 may have been confirmed by the separate treatment of Wartislaw II and Swietopelk in the Kamien pact from 1264. It is also possible that this document confirmed the fact that his father chose Wartislaw as the successor to the function of the princeps or just the ruler of Gdańsk. In light of other sources, however, it is more likely that Swietopelk did not make any final decisions in this regard and that Wartislaw was elected the ruler of Gdańsk in 1266 by the gentry. 